\title{
PENGARUH PEMANFAATAN TEPUNG BUAH KERSEN (MUNTINGIA CALABURA L.) DAN SUBSTITUSI GULA TERHADAP KANDUNGAN GIZI, ANTIOKSIDAN DAN ORGANOLEPTIK BISKUIT
}

\author{
The Effect of Calabura Fruit (Muntingia calabura L.) Flour Utilization and Sugar Substitution \\ on Nutritional, Antioxidants and Organoleptics of Biscuit \\ Deya Silviani ${ }^{1}$, Sri Anna Marliyati ${ }^{*}$, Lilik Kustiyah ${ }^{1}$ \\ 1-2 Departemen Gizi Masyarakat, Fakultas Ekologi Manusia, IPB University, Bogor, Indonesia \\ *E-mail: anna_marliyati@yahoo.com
}

\begin{abstract}
ABSTRAK
Perubahan pola konsumsi ke pola yang kurang sehat seperti peningkatan konsumsi gula dan rendahnya konsumsi sayur dan buah, berkontribusi terhadap peningkatan prevalensi overweight dan obesitas di Indonesia. Overweight dan obesitas merupakan faktor risiko penyakit tidak menular. Pada penderita obesitas terjadi peningkatan stres metabolik, yang lebih lanjut dapat memicu penyakit tidak menular. Buah kersen (Muntingia calabura L.) memiliki potensi gizi dan antioksidan yang dapat dimanfaatkan pada pengembangan produk pangan. Pemanfaatan buah kersen dan substitusi gula pada biskuit dapat dilakukan sebagai upaya untuk membuat produk biskuit menjadi lebih bergizi, mengandung antioksidan dan lebih rendah gula yang dapat berkontribusi pada pencegahan faktor risiko overweight dan obesitas. Penelitian ini bertujuan untuk menganalisis pengaruh pemanfaatan tepung buah kersen dan substitusi gula terhadap kandungan gizi, kandungan antioksidan, aktivitas antioksidan, karakteristik organoleptik serta karakteristik fisik biskuit. Rancangan Percobaan yang digunakan adalah Rancangan Acak Lengkap Faktorial dengan dua faktor, yaitu substitusi tepung buah kersen dan substitusi gula. Analisis yang dilakukan meliputi analisis kandungan gizi, kadar dan aktivitas antioksidan, dan kekerasan. Pengaruh perlakuan terhadap kandungan zat gizi dianalisis menggunakan sidik ragam (ANOVA), sedangkan terhadap sifat organoleptik menggunakan Kruskal Wallis. Hasil penelitian menunjukkan bahwa substitusi tepung buah kersen dan gula memberikan pengaruh terhadap kadar abu serta kandungan dan aktivitas antioksidan biskuit $(\mathrm{p}<0,05)$, namun tidak berpengaruh pada karakteristik organoleptik biskuit. Peningkatan taraf substitusi tepung buah kersen meningkatkan aktivitas dan kadar antioksidan biskuit.
\end{abstract}

Kata kunci: antioksidan, gula pengganti, Muntingia calabura L., obesitas, penyakit tidak menular

\section{ABSTRACT}

Changes in dietary pattern to unhealthy, such as increased in sugar and low of fruits and vegetables consumption, are among factors contribute to the increase of overweight and obesity prevalence in Indonesia. Overweight and obesity are risk factors of non-communicable diseases. Obese people had increased of metabolic stress, further lead to noncommunicable diseases. Calabura fruit (Muntingia calabura L.) has nutritional and antioxidant potential, which can be utilized in the development of food products. The utilization of Calabura fruit and sugar substitution in biscuits could be done as an effort to make healthy biscuits, contain antioxidants and lower sugar, which may contribute to the prevention of overweight and obesity. This research aims to analyze the effect of utilization of Calabura fruit flour and sugar substitution on the nutritional, antioxidant, antioxidant activity, organoleptic and physical characteristics of biscuits. An experimental study was conducted by using completely randomized factorial design with two factors: the substitution of Calabura fruit flour and sugar substitution. The analysis included nutrients and antioxidants content, antioxidant activity, and hardness of biscuits. The effect of treatment on nutritional content was analyzed using ANOVA and the Kruskal Wallis test for organoleptic. The results show that Calabura fruit flour and sugar substitution significantly affect ash, antioxidants content, and antioxidant activity of biscuit $(p<0,05)$, but has no effect on organoleptic characteristics. The increased level of Calabura flour substitution improves antioxidant content and antioxidant activity in biscuits.

Keywords - antioxidants, sugar replacer, Muntingia calabura L., obesity, non-communicable diseases 


\section{PENDAHULUAN}

Kondisi overweight dan obesitas di Indonesia saat ini semakin mengalami peningkatan dari tahun ke tahun. Prevalensi obesitas pada dewasa usia 18 tahun ke atas meningkat dari $14,8 \%$ pada 2013 menjadi $21,8 \%$ pada 2018 (Kemenkes, 2018). Kondisi ini erat kaitannya dengan kejadian berbagai penyakit termasuk penyakit tidak menular seperti penyakit jantung, stroke, diabetes mellitus dan sebagainya. Tingkat morbiditas dan mortalitas pada penderita obesitas meningkat dengan umur harapan hidup yang lebih pendek (Syafiq et al., 2014). Pada kondisi obesitas terjadi pembentukan lemak tubuh yang berlebihan, penghambatan pemecahan lemak dan inflamasi (Susantiningsih, 2015). Inflamasi yang disebabkan obesitas secara lebih lanjut menyebabkan perubahan kondisi metabolik seperti stres metabolik. Stres metabolik juga berkaitan dengan stres oksidatif dalam tubuh yaitu ketidakseimbangan antara radikal bebas dan antioksidan. Stres oksidatif dalam tubuh menyebabkan kerusakan sel, jaringan atau organ, yang lebih lanjut memicu patogenesis penyakitpenyakit tidak menular. Protein penanda inflamasi (C-Reactive Protein; CRP) pada obesitas 10 kali lebih tinggi dibandingkan normal (Cave, Hurt, \& Frazier, 2008).

Perubahan pola konsumsi kepada makanan tinggi lemak, tinggi gula, rendah serat dan antioksidan, serta rendahnya aktivitas fisik merupakan beberapa penyebab overweight dan obesitas. Siervo et al. (2013) menunjukkan bahwa konsumsi makanan dan minuman tinggi gula berhubungan dengan peningkatan prevalensi berat badan lebih $(\rho=0,37, P<0,001)$ dan obesitas ( $\rho=0,31, P<0,001$ ), di mana faktor konsumsi energi dari gula merupakan prediktor obesitas $(\mathrm{B}=0,04, \mathrm{SE}=0,01, \mathrm{p}=0,009)$. Selain itu, rendahnya konsumsi serat dan makanan sumber antioksidan menjadi faktor pencetus kegemukan yang tidak kalah penting. Hal ini ditunjukkan dari rendahnya konsumsi sayur dan buah pada masyarakat Indonesia. Sebagian besar $(95,5 \%)$ masyarakat usia $\geq 5$ tahun mengonsumsi sayur dan buah di bawah anjuran pedoman gizi seimbang 5 porsi sehari (Kemenkes, 2018).

Organisasi Kesehatan Dunia (WHO) menyebutkan bahwa senyawa bioaktif penting untuk pencegahan penyakit diabetes, kanker dan obesitas terutama dari buah-buahan kecil berwarna (Stapleton et al., 2008). Buah kersen (Muntingia calabura L.) merupakan buah yang memiliki potensi gizi dan bioaktif antioksidan. Buah ini tumbuh luas di beberapa negara termasuk Indonesia. Kandungan gizi buah kersen meliputi air (77,36\%), abu (5,65\%), karbohidrat (72,15\%), protein $(8,29 \%)$, lemak $(7,79 \%)$, serat kasar $(5,93 \%)$, dan vitamin C (3,30 mg per $100 \mathrm{~g})$, dengan nilai energi total yang rendah (Pereira et al., 2016). Selain itu, buah kersen berkontribusi pada senyawa bioaktif antioksidan seperti asam fenolik, antosianin dan flavonoid yang menunjukkan bioaktivitas antimikroba, antioksidan dan antiinflamasi. Aktivitas antiinflamasi flavons, flavonols (rutin, quercetin, kaempferol, mirisetin) dan beberapa terpenoid pada buah kersen dapat menghambat ekspresi COX dan lipopolisakarida yang bertanggung jawab pada kejadian inflamasi (Gomathi, Anusuya, \& Manian, 2013). Buah kersen mengandung senyawa fenolik sebesar $526,55 \mathrm{mg}$ asam tanin ekuivalen (TAE) per $100 \mathrm{~g}$, antosianin 4,08 mg sianidin-3-glukosida ekuivalen (CGE) per $100 \mathrm{~g}$ dan aktivitas antioksidan DPPH IC50 $(82,25$ $\mu \mathrm{g} / \mathrm{mL}$ ) (Pereira et al., 2016). Namun, potensi dari buah kersen masih belum dimanfaatkan secara optimal. Buah kersen hanya dikonsumsi sesekali dan pohonnya secara umum hanya dimanfaatkan sebagai pohon peneduh pinggir jalan.

Buah kersen berpeluang untuk digunakan dalam menghasilkan produk pangan dengan kandungan gizi dan manfaat bioaktif antioksidan. Produk pangan seperti biskuit memiliki peluang untuk dikembangkan disebabkan tingginya konsumsi, disukai, praktis dan memiliki keawetan yang baik. Biskuit yang beredar di masyarakat umumnya memiliki kandungan karbohidrat dan gula yang tinggi serta rendah serat dan antioksidan. Saat ini, mulai bermunculan produsen makanan yang berupaya menghasilkan produk pangan yang lebih sehat. Selain itu, beberapa penelitian pada produk biskuit dilakukan untuk menghasilkan biskuit yang memiliki kandungan gizi dan memiliki manfaat kesehatan dengan cara mengombinasikan dan memanfaatkan bahan-bahan berpotensi gizi serta meminimalkan penggunaan gula. Oleh karena itu, pemanfaatan buah kersen dalam menghasilkan biskuit yang bergizi dan mengandung antioksidan menarik untuk dilakukan 
sebagai upaya menghasilkan produk pangan yang berkontribusi pada pencegahan penyakit tidak menular terutama dari faktor risiko overweight dan obesitas. Penelitian ini bertujuan untuk melihat pengaruh pemanfaatan buah kersen dan substitusi gula pada kandungan gizi, antioksidan dan organoleptik biskuit.

\section{METODE}

Desain penelitian ini adalah eksperimental menggunakan rancangan acak lengkap faktorial berupa faktor substitusi tepung buah kersen dan substitusi gula pada biskuit berbasis parsial mocaf. Buah kersen diolah menjadi tepung buah kersen sebelum digunakan dalam pembuatan biskuit. Tepung buah kersen dibuat dengan cara pengeringan menggunakan alat vakum evaporator, kemudian penggilingan dan pengayakan 40 mesh. Taraf tepung buah kersen untuk substitusi parsial terigu mocaf yaitu $11 \%, 17 \%$ dan $22 \%$ terhadap total tepung terigu dan mocaf, dan taraf substitusi gula yaitu $40 \%$ dan $50 \%$ dari total gula, menggunakan campuran 2 jenis pemanis yang dihitung setara dengan kemanisan sukrosa. Pemanis yang digunakan adalah sorbitol dan Diabetasol sukralosa. Formulasi biskuit disajikan pada Tabel 1.

Proses pembuatan biskuit dengan metode creaming, diawali dengan pencampuran bahan basah kemudian pencampuran bahan kering tepung-tepungan hingga adonan tercampur rata. Selanjutnya, pencetakan adonan setebal $4 \mathrm{~mm}$ dan pemanggangan pada suhu $160^{\circ} \mathrm{C}$ selama 15 menit. Uji organoleptik terhadap biskuit dilakukan menggunakan uji hedonik pada atribut rasa, aroma, warna, tekstur (mouthfeel) dan keseluruhan. Skala penilaian dari 1 hingga 7, yaitu 1 (Sangat tidak suka), 2 (Tidak suka), 3 (Agak tidak suka), 4 (Biasa), 5 (Agak suka), 6 (Suka), dan 7 (Sangat suka) oleh 31 orang panelis semi terlatih. Analisis kandungan gizi, sifat fisik kekerasan, aktivitas antioksidan dan kadar antioksidan dilakukan terhadap seluruh formula biskuit. Analisis kandungan gizi meliputi kadar air menggunakan metode oven, kadar abu menggunakan metode gravimetri, kadar protein metode Kjeldahl menggunakan Foss Tecator Kjeltec KT 200, kadar lemak metode Soxhlet menggunakan Foss Soxtec ST 243 dan kadar karbohidrat by difference (AOAC, 2005). Aktivitas antioksidan metode DPPH mengacu Molyneux (2004) dan Preethi, Vijayalakshmi, Shamna, \& Sasikumar (2010) dengan modifikasi. Analisis kadar antioksidan kuantitatif meliputi total fenol menggunakan metode Folin-Ciocalteau (Vongsak, Sithisarn, \& Mangmool, 2013), total flavonoid metode kolorimetri $\mathrm{AlCl}_{3}$ (Recuenco, Lacsamana, $\&$ Sabularse, 2016), dan antosianin total (Lao

Tabel 1. Formulasi Biskuit

\begin{tabular}{|c|c|c|c|c|c|c|c|}
\hline \multirow{2}{*}{ Formula (g) } & \multicolumn{7}{|c|}{ Berat bahan (g) } \\
\hline & kontrol & F1 & F2 & F3 & F4 & F5 & F6 \\
\hline Tepung terigu & 45 & 40 & 37,5 & 35 & 40 & 37,5 & 35 \\
\hline Tepung mocaf & 45 & 40 & 37,5 & 35 & 40 & 37,5 & 35 \\
\hline Pati jagung & 10 & 10 & 10 & 10 & 10 & 10 & 10 \\
\hline Tepung kersen* & - & 10 & 15 & 20 & 10 & 15 & 20 \\
\hline Susu bubuk skim & 2 & 2 & 2 & 2 & 2 & 2 & 2 \\
\hline Kuning telur & 10 & 10 & 10 & 10 & 10 & 10 & 10 \\
\hline Garam & 0,6 & 0,6 & 0,6 & 0,6 & 0,6 & 0,6 & 0,6 \\
\hline Gula aren* & 25 & 15 & 15 & 15 & 12,5 & 12,5 & 12,5 \\
\hline Sorbitol* & - & 13,5 & 13,5 & 13,5 & 16,5 & 16,5 & 16,5 \\
\hline Gula sukralosa* & - & 0,2 & 0,2 & 0,2 & 0,25 & 0,25 & 0,25 \\
\hline Mentega & 16 & 16 & 16 & 16 & 16 & 16 & 16 \\
\hline Margarin & 16 & 16 & 16 & 16 & 16 & 16 & 16 \\
\hline Vanili esens & 0,4 & 0,4 & 0,4 & 0,4 & 0,4 & 0,4 & 0,4 \\
\hline Baking powder & 0,25 & 0,25 & 0,25 & 0,25 & 0,25 & 0,25 & 0,25 \\
\hline Total adonan & 170 & 175 & 175 & 175 & 175 & 175 & 175 \\
\hline
\end{tabular}

Keterangan: *variabel perlakuan 
\& Giusti, 2015). Analisis fisik kekerasan diukur menggunakan Stevens-LFRA Texture Analyzer.

Data yang terkumpul ditabulasi dan dianalisis menggunakan Excel dan SPSS 16.0 for Windows. Semua data diuji normalitas sebelum diuji statistik. Data hasil uji organoleptik dianalisis menggunakan Kruskal Wallis yang disajikan dalam nilai modus dan persentase panelis. Hasil analisis kimia dianalisis secara statistik menggunakan two-way ANOVA $(\alpha=0,05)$, diikuti dengan uji lanjut Duncan bila terdapat pengaruh signifikan. Sifat fisik kekerasan biskuit dianalisis secara deskriptif.

\section{HASIL DAN PEMBAHASAN}

\section{Uji Organoleptik Biskuit}

Hasil uji organoleptik disajikan pada Tabel 2. Berdasarkan uji statistik Kruskal Wallis, seluruh perlakuan tidak berpengaruh signifikan $(p>0,05)$ terhadap tingkat kesukaan panelis pada atribut warna, rasa, aroma, tekstur (mouthfeel) dan keseluruhan. Namun, berdasarkan kecenderungan data, F5 paling disukai (modus 6) dengan persentase jumlah panelis tertinggi pada atribut warna. Warna biskuit relatif cokelat. Kombinasi penggunaan tepung buah kersen dengan warna ${ }^{\circ}$ Hue kuning merah dan gula aren memberikan warna coklat pada biskuit, selain efek reaksi Maillard yang terjadi selama pemanggangan. Warna coklat juga berasal dari interaksi antioksidan fenol dengan bahan biskuit. Oksidasi fenol oleh pengaruh enzim, pemanasan dan $\mathrm{pH}$ tinggi menghasilkan quinon yang menghasilkan pigmen warna coklat (Bittner, 2006). Hal ini sebagaimana (Ou \& Wang, 2019) dimana senyawa fenolik, taraf penambahan bahan mengandung fenolik dan suhu pemanggangan dapat mempengaruhi warna Berdasarkan rasa, $\mathrm{F} 1$ disukai dengan persen modus tertinggi (40\%). F1 juga paling disukai dari segi aroma dengan nilai modus 6 (suka) dan persentase panelis tertinggi (40\%).

Atribut sensori produk panggang dapat dipengaruhi oleh penggunaan by-product yang mengandung antioksidan fenolik. Penambahan $20 \%$ pomace buah campuran blackcurrant, rowan, rosehip dan elderberry pada cookies menurunkan penilaian terhadap aroma dengan aroma panggang yang rendah (Tańska, Roszkowska, \& Czaplicki, 2016). Keberadaan polifenol menghambat pembentukan senyawa aroma dan flavor yang dihasilkan dari reaksi mekanisme penangkapan senyawa karbonil dari fragmentasi gula selama pemanggangan pada produk panggang (Ou \& Wang, 2019).

Peningkatan taraf substitusi gula menurunkan jumlah gula yang terlibat pada reaksi Maillard sehingga senyawa karbonil yang terbentuk lebih sedikit. Kandungan fenolik dalam tepung buah dan interaksinya dengan gula dapat menurunkan pembentukan senyawa flavor dan aroma biskuit. Pengaruh taraf substitusi tepung buah kersen dan gula terhadap atribut sensori pada penelitian ini tidak berbeda signifikan, namun dilaporkan menghasilkan aroma dan rasa buah kersen yang lemah yang masih disukai panelis.

Atribut tekstur disukai oleh panelis (modus 6) pada formula F2 dan F4. Formula F6 memiliki modus tekstur terendah yaitu 4 (biasa) di antara formula lainnya. Penggunaan tepung buah kersen pada tingkat substitusi tertinggi pada

Tabel 2. Hasil Uji Kesukaan (Hedonik)

\begin{tabular}{lccccc}
\hline \multirow{2}{*}{ Formula } & \multicolumn{5}{c}{ Atribut } \\
\cline { 2 - 5 } & Warna & Rasa & Aroma & Tekstur & Keseluruhan \\
\hline F1 & $5(33,3)^{\mathrm{a}}$ & $6(40,0)^{\mathrm{a}}$ & $6(40,0)^{\mathrm{a}}$ & $5(33,3)^{\mathrm{a}}$ & $6(36,7)^{\mathrm{a}}$ \\
F2 & $6(46,7)^{\mathrm{a}}$ & $6(30,0)^{\mathrm{a}}$ & $4(33,3)^{\mathrm{a}}$ & $6(40,0)^{\mathrm{a}}$ & $6(30,0)^{\mathrm{a}}$ \\
F3 & $6(40,0)^{\mathrm{a}}$ & $5(30,0)^{\mathrm{a}}$ & $4(26,7)^{\mathrm{a}}$ & $5(33,3)^{\mathrm{a}}$ & $5(26,7)^{\mathrm{a}}$ \\
F4 & $6(33,3)^{\mathrm{a}}$ & $5(26,7)^{\mathrm{a}}$ & $6(30,0)^{\mathrm{a}}$ & $6(30,0)^{\mathrm{a}}$ & $5(36,7)^{\mathrm{a}}$ \\
F5 & $6(50,0)^{\mathrm{a}}$ & $6(26,7)^{\mathrm{a}}$ & $6(26,7)^{\mathrm{a}}$ & $5(33,3)^{\mathrm{a}}$ & $5(36,7)^{\mathrm{a}}$ \\
F6 & $5(33,3)^{\mathrm{a}}$ & $5(43,3)^{\mathrm{a}}$ & $6(33,3)^{\mathrm{a}}$ & $4(30,0)^{\mathrm{a}}$ & $6(30,0)^{\mathrm{a}}$ \\
Nilai p & 0,202 & 0,360 & 0,833 & 0,305 & 0,580 \\
\hline
\end{tabular}

Keterangan: Skala $1=$ sangat tidak suka, $2=$ tidak suka, $3=$ agak tidak suka, $4=$ biasa, $5=$ agak suka, $6=$ suka, $7=$ sangat suka. Tepung kersen $(\mathrm{TK})$, Substitusi gula (SG). Formula=TK:SG. F1=11\%:40\%, F2 = 17\%:40\%, F3 = 22\%:40\%, F4 = 11:50\%, F5=17\%:50\% dan F6=22\%:50\%. Huruf yang sama pada kolom yang sama menunjukkan tidak berbeda signifikan ( $\mathrm{p}>0,05)$. 
F6 menyebabkan tekstur yang kurang disukai. Beberapa panelis melaporkan tekstur biskuit yang kurang rapuh beremah dan crunchy renyah. Atribut keseluruhan menunjukkan bahwa formula yang disukai panelis (modus 6) yaitu F1, F2 dan F6. Nilai persentase panelis tertinggi terhadap kesukaan atribut keseluruhan biskuit kersen diperoleh oleh F1.

\section{Kandungan Zat Gizi Biskuit}

Kadar air biskuit kersen berkisar 2,994,58\% (Tabel 3). Kadar air biskuit tidak berbeda signifikan $(\mathrm{p}>0,05)$ antar taraf dan interaksi substitusi tepung buah kersen dan gula. Namun, kadar air biskuit memperlihatkan kecenderungan peningkatan seiring peningkatan substitusi tepung buah kersen. Tepung buah kersen mengandung air yang akan meningkatkan kadar air biskuit seiring peningkatan substitusi tepung. Selain itu, peningkatan taraf substitusi gula menunjukkan kecenderungan penurunan kadar air biskuit. Hal ini disebabkan terbentuknya air terikat dalam biskuit oleh perlakuan substitusi gula. Air terikat adalah air yang berikatan suatu senyawa. Penggunaan gula sorbitol dan keberadaan gum arab dalam tepung buah kersen bersifat mengikat air (higroskopis). Air terikat ini akan sulit dan sedikit diuapkan ketika proses pemanggangan sehingga kadar air dalam biskuit tertahan (Barbosa-Cánovas et al., 2003). Kadar air yang sedikit teruapkan menyebabkan penilaian kadar air menjadi lebih rendah.

Kadar abu biskuit berkisar 1,51-1,97\%. Interaksi perlakuan substitusi tepung buah kersen dan substitusi gula tidak memberikan perbedaan kadar abu yang signifikan. Kadar abu menunjukkan perbedaan signifikan dari perbedaan taraf substitusi tepung buah kersen berdasarkan uji two-way ANOVA $(\mathrm{p}<0,05)$. Semakin tinggi substitusi tepung buah kersen meningkatkan kadar abu biskuit. Kadar abu total menunjukkan kandungan mineral total dalam makanan (Nielsen, 2010). Buah kersen mengandung mineral yang berkontribusi pada peningkatan kadar abu biskuit. Buah kersen mengandung kadar abu dengan kandungan 16 jenis mineral di mana zat besi (Fe) sebagai mineral mikro tertinggi dan kalium sebagai mineral makro tertinggi (Muslimin et al., 2019).

Kadar protein, lemak dan karbohidrat biskuit tidak berbeda signifikan oleh perbedaan taraf dan interaksi substitusi tepung buah kersen dan substitusi gula. Kadar protein, lemak dan karbohidrat biskuit berkisar 4,58-4,96 \%, 19,62$19,90 \%$ dan $73,43-74,02 \%$, secara berturut-turut. Kandungan protein, lemak, karbohidrat pada buah kersen kurang memberi kontribusi signifikan pada biskuit. Peningkatan taraf substitusi gula juga tidak memberikan pengaruh signifikan terutama pada karbohidrat diduga disebabkan perbedaan antar perlakuan taraf substitusi gula yang kecil.

Aktivitas dan kadar antioksidan biskuit Interaksi taraf substitusi tepung buah kersen dan gula menunjukkan pengaruh signifikan $(\mathrm{p}<0,05)$ terhadap persen penghambatan, total fenol, antosianin dan aktivitas antioksidan. Aktivitas antioksidan biskuit dinyatakan dalam persen penghambatan dan kesetaraan dengan asam

Tabel 3. Kandungan Gizi Biskuit per $100 \mathrm{~g}$

\begin{tabular}{lccccc}
\hline \multirow{2}{*}{ Formula } & \multicolumn{5}{c}{ Kandungan gizi (x \pm SD) } \\
\cline { 2 - 6 } & Air & Abu & Protein & Lemak & Karbohidrat \\
\hline F1 & $3,49^{\mathrm{a}} \pm 0,13$ & $1,62^{\mathrm{ab}} \pm 0,07$ & $4,96^{\mathrm{a}} \pm 0,32$ & $19,90^{\mathrm{a}} \pm 0,36$ & $73,52^{\mathrm{a}} \pm 0,76$ \\
F2 & $4,17^{\mathrm{a}} \pm 0,92$ & $1,69^{\mathrm{ab}} \pm 0,05$ & $4,63^{\mathrm{a}} \pm 0,09$ & $19,64^{\mathrm{a}} \pm 0,38$ & $74,02^{\mathrm{a}} \pm 0,53$ \\
F3 & $4,58^{\mathrm{a}} \pm 0,67$ & $1,97^{\mathrm{a}} \pm 0,17$ & $4,91^{\mathrm{a}} \pm 0,32$ & $19,69^{\mathrm{a}} \pm 0,58$ & $73,43^{\mathrm{a}} \pm 1,08$ \\
F4 & $2,99^{\mathrm{a}} \pm 0,79$ & $1,51^{\mathrm{a}} \pm 0,07$ & $4,84^{\mathrm{a}} \pm 0,11$ & $19,62^{\mathrm{a}} \pm 0,80$ & $74,02^{\mathrm{a}} \pm 0,83$ \\
F5 & $3,62^{\mathrm{a}} \pm 1,59$ & $1,72^{\mathrm{ab}} \pm 0,09$ & $4,58^{\mathrm{a}} \pm 0,01$ & $19,85^{\mathrm{a}} \pm 0,73$ & $73,84^{\mathrm{a}} \pm 0,81$ \\
F6 & $3,92^{\mathrm{a}} \pm 0,16$ & $1,79^{\mathrm{bc}} \pm 0,01$ & $4,83^{\mathrm{a}} \pm 0,0007$ & $19,68^{\mathrm{a}} \pm 0,57$ & $73,68^{\mathrm{a}} \pm 0,56$ \\
Nilai p & & & & & 0,803 \\
\hline Faktor A & 0,316 & 0,010 & 0,143 & 0,982 & 0,689 \\
\hline Faktor B & 0,299 & 0,160 & 0,502 & 0,948 & 0,825 \\
\hline Interaksi & 0,991 & 0,356 & 0,969 & 0,850 & 0,803 \\
\hline
\end{tabular}

Keterangan: Faktor A=Tepung kersen (TK), Faktor B= substitusi gula (SG). Formula=TK:SG. F1=11\%:40\%, F2 = 17\%:40\%, F3=22\%:40\%, F4 $=11: 50 \%, \mathrm{~F} 5=17 \%: 50 \%$ dan $\mathrm{F} 6=22 \%: 50 \%$. Huruf yang sama pada kolom yang sama menunjukkan tidak berbeda signifikan $(\mathrm{p}>0,05)$. 
askorbat (Ascorbic acid Equivalent Antioxidant Capacity; AEAC).

Persen penghambatan biskuit kersen berkisar 48,78\% hingga tertinggi sebesar 93,84\% (Tabel 4). Taraf minimal substitusi tepung buah kersen ke dalam biskuit sebesar $11 \%$ memiliki persen penghambatan sebesar $48,78 \%$ (F1) dan $65,56 \%$ (F4). Persen penghambatan ini tidak berbeda jauh dengan hasil penelitian Srivastava, Indrani, \& Singh (2014) menggunakan tepung kulit delima, di mana biskuit dengan substitusi $7,5 \%$ tepung kulit delima menunjukkan persen penghambatan sebesar $52,71 \%$. Penggunaan substitusi tepung buah pada biskuit memiliki kemampuan meredam radikal bebas DPPH setara dengan $82,16 \mathrm{mg}$ hingga 159,33 mg asam askorbat per $100 \mathrm{~g}$ biskuit. Aktivitas antioksidan biskuit ini tidak berbeda dengan cookies sagu 7,5\% pegagan (Saputri \& Damayanthi, 2015) dengan aktivitas antioksidan $140 \mathrm{mg}$ asam askorbat per $100 \mathrm{~g}$. Peningkatan substitusi tepung buah kersen meningkatkan aktivitas antioksidan biskuit. Hasil ini sejalan dengan beberapa penelitian. Penggunaan tepung buah mangga pada biskuit meningkatkan antioksidan dan

polifenol (Ajila, Leelavathi, \& Rao, 2008). Srivastava et al. (2014) menunjukkan adanya peningkatan persen aktivitas antioksidan biskuit dengan peningkatan tepung kulit buah delima dibandingkan kontrol. Aktivitas antioksidan biskuit disebabkan masih ada senyawa antioksidan alami yang tertahan selama pemanggangan dari tepung buah kersen. Buah kersen mengandung kadar fenolik tinggi terutama asam fenolik dan flavonoid dengan aktivitas antioksidan tinggi DPPH IC50 $82,25 \mu \mathrm{g} / \mathrm{mL}$ (Pereira et al., 2016). Besar aktivitas antioksidan biskuit mungkin juga disumbang oleh senyawa melanoidin yang dihasilkan dari reaksi Maillard selama pemanggangan. Melanoidin memiliki aktivitas antioksidan tinggi (Manzocco, et al., 2001).

Fenol adalah antioksidan kuat yang memiliki peran penting pada kesehatan. Kadar total fenol biskuit berkisar 81,68-140,77 mg GAE/100 g. Peningkatan substitusi tepung buah kersen dan gula cenderung menghasilkan biskuit dengan kadar fenol yang berbeda signifikan $(\mathrm{p}<0,05)$. Kadar fenol biskuit meningkat seiring peningkatan substitusi tepung buah kersen. Hal ini juga ditunjukkan oleh Aksoylu \& Çag (2015) di mana terdapat peningkatan aktivitas antioksidan dan total fenol dengan penggunaan blueberry atau tepung biji anggur pada biskuit.

Kadar total flavonoid biskuit berkisar 17,96-29,43 mg quercetin/100 g. Total flavonoid biskuit tidak berbeda signifikan $(p>0,05)$ oleh pengaruh interaksi taraf substitusi tepung buah kersen dan gula. Namun, perbedaan taraf substitusi tepung buah kersen menunjukkan perbedaan yang signifikan $(\mathrm{p}<0,05)$. Hasil ini sejalan dengan Pasqualone et al. (2014) di mana terdapat peningkatan kadar flavonoid dengan penggunaan semolina dan ekstrak ampas anggur yang berkontribusi pada senyawa volatil.

Kadar total antosianin biskuit berada pada kisaran 1,47-2,33 mg/100 g. Antosianin merupakan

Tabel 4. Aktivitas dan Kadar Antioksidan Biskuit

\begin{tabular}{|c|c|c|c|c|c|}
\hline \multirow{2}{*}{ Formula } & \multicolumn{2}{|c|}{ Aktivitas antioksidan } & \multirow{2}{*}{$\begin{array}{c}\text { Fenol (mg GAE/100 } \\
\text { g) }\end{array}$} & \multirow{2}{*}{$\begin{array}{c}\text { Flavonoid (mg } \\
\text { quercetin/100 g) }\end{array}$} & \multirow{2}{*}{$\begin{array}{c}\text { Antosianin (mg/100 } \\
\mathrm{g})\end{array}$} \\
\hline & $\%$ penghambatan & AEAC (mg/100 g) & & & \\
\hline F1 & $48,78^{\mathrm{a}} \pm 3,92$ & $82,16^{\mathrm{a}} \pm 6,55$ & $81,68^{\mathrm{a}} \pm 5,07$ & $17,96^{\mathrm{a}} \pm 4,06$ & $1,51^{\mathrm{a}} \pm 0,014$ \\
\hline $\mathrm{F} 2$ & $84,49^{b} \pm 1,76$ & $142,88^{b} \pm 2,96$ & $127,21^{\mathrm{b}} \pm 0,44$ & $24,96^{\mathrm{bc}} \pm 2,55$ & $1,68^{\mathrm{b}} \pm 0,00$ \\
\hline F3 & $93,84^{c} \pm 0,06$ & $159,33^{\mathrm{c}} \pm 0,11$ & $127,67^{b} \pm 0,29$ & $29,43^{c} \pm 2,57$ & $2,33^{\mathrm{c}} \pm 0,01$ \\
\hline $\mathrm{F} 4$ & $65,56^{\mathrm{d}} \pm 0,50$ & $109,65^{\mathrm{d}} \pm 0,83$ & $106,47^{\mathrm{c}} \pm 2,81$ & $19,30^{\mathrm{ab}} \pm 2,02$ & $1,47^{\mathrm{d}} \pm 0,00$ \\
\hline F5 & $86,33^{b} \pm 5,48$ & $145,15^{\mathrm{b}} \pm 9,18$ & $119,52^{b} \pm 0,72$ & $19,79^{\mathrm{ab}} \pm 1,53$ & $1,62^{\mathrm{e}} \pm 0,00$ \\
\hline F6 & $91,27^{\mathrm{bc}} \pm 0,00$ & $153,91^{\mathrm{bc}} \pm 0,09$ & $140,77^{\mathrm{d}} \pm 8,43$ & $23,81^{\mathrm{abc}} \pm 0,00$ & $2,12^{\mathrm{f}} \pm 0,01$ \\
\hline \multicolumn{6}{|l|}{ Nilai $\mathrm{p}$} \\
\hline Faktor A & 0,000 & 0,000 & 0,000 & 0,011 & 0,000 \\
\hline Faktor B & 0,017 & 0,026 & 0,006 & 0,068 & 0,000 \\
\hline Interaksi & 0,007 & 0,007 & 0,004 & 0,160 & 0,000 \\
\hline
\end{tabular}

Keterangan: Faktor A=Tepung kersen (TK), Faktor B= substitusi gula (SG). Formula=TK:SG. F1= 10\%:40\%, F2=15\%:40\%, F3=20\%:40\%, F4 $=10: 50 \%, F 5=15 \%: 50 \%$ dan F6=20\%:50\%. Huruf yang sama pada kolom yang sama menunjukkan tidak berbeda signifikan ( $>0.05$ ). 
antioksidan yang tidak stabil selama pengolahan terutama rusak akibat perlakuan panas dan $\mathrm{pH}$. Kadar antosianin biskuit kersen tidak berbeda jauh dengan antosianin biskuit dari tepung gandum ungu (Pasqualone et al., 2015) sebesar 1,38 mg/100 g.

Aktivitas antioksidan, fenol, flavonoid dan antosianin menunjukkan peningkatan dengan penggunaan tepung buah kersen pada biskuit, namun pengaruh gula belum terlihat jelas meski hasil statistik menunjukkan perbedaan signifikan. Meskipun demikian, diduga antioksidan fenolik memiliki interaksi dengan gula. Beberapa polifenol menangkap senyawa karbonil dan aldehid hasil dari pemecahan gula dan oksidasi lemak, serta bereaksi dengan senyawa flavor pada produk panggang $(\mathrm{Ou}$ \& Wang, 2019). Antioksidan polifenol termasuk flavonoid dan antosianin dapat memberikan manfaat kesehatan dengan menurunkan inflamasi dan disfungsi metabolik terkait stres oksidatif, salah satunya melalui perbaikan biomarker status antioksidan (Bindels et al., 2013; Farrell et al., 2015; Gentile et al., 2018).

\section{Korelasi Fenol dengan Aktivitas Antioksidan dan Antioksidan}

Kadar fenol yang meningkat seiring peningkatan tepung buah kersen berhubungan positif yang sangat kuat dengan peningkatan aktivitas antioksidan pada biskuit $(\mathrm{r}=0,886)$ (Tabel 5). Hasil ini sejalan dengan penelitian Kumar, Sandhir, \& Ojha (2014) yang menunjukkan hubungan positif antara aktivitas antioksidan dan kadar fenol pada ekstrak daun lantana camara $(r=$ $0,994)$. Hubungan yang sangat kuat menunjukkan senyawa fenol berkontribusi utama pada aktivitas antioksidan biskuit kersen. Nilai aktivitas antioksidan total mengikuti tren yang sama dengan kandungan fenol dalam ekstrak (Kumar et al., 2014).

Fenol merupakan kelompok besar antioksidan yang meliputi flavonoid dan antosianin. Aktivitas antioksidan menggambarkan gabungan pengaruh dari senyawa fenolik, flavonoid dan senyawa lainnya dalam ekstrak tanaman. Sun et al. (2002) menyatakan bahwa keberadaan fenol, flavonoid dan antosianin pada makanan berhubungan dengan aktivitas antioksidan. Hal ini didukung oleh Pereira et al. (2018) bahwa buah kersen menunjukkan
Tabel 5. Korelasi Fenol dengan Aktivitas Antioksidan, Flavonoid dan Antosianin

\begin{tabular}{lcc}
\hline \multicolumn{1}{c}{ Variabel korelasi } & p & r \\
\hline Fenol - \% penghambatan & 0,000 & $0,886^{* *}$ \\
Fenol - flavonoid & 0,021 & $0,656^{*}$ \\
Fenol - antosianin & 0,001 & $0,837^{* *}$ \\
\hline
\end{tabular}

Keterangan:*korelasi kuat, ${ }^{* *}$ korelasi sangat kuat

aktivitas antioksidan yang tinggi karena keberadaan antosianin, asam fenolik dan flavonoid.

Flavonoid dan antosianin berkontribusi signifikan terhadap total fenol pada biskuit ditunjukkan dengan korelasi yang kuat antara fenol dan flavonoid serta korelasi sangat kuat antara fenol dan antosianin. Flavonoid diperkirakan menyusun $2 / 3$ dari fenol. Flavonoid pada buah kersen berupa rutin, quercetin, mirisetin. Penelitian in vitro oksidasi menunjukkan quercetin, mirisetin dan rutin bertindak sebagai antioksidan yang lebih kuat daripada vitamin (Miean \& Mohamed, 2001). Pereira et al. (2018) menyebutkan bahwa antiosianin utama pada buah kersen adalah cyanidin-3-O-glukosida (97\% dari fraksi antosianin). Cyanidin-3-O-glukosida memiliki aktivitas antioksidan yang lebih kuat dibanding peonidin atau malvidin glikosida (Wang, Cao, \& Prior, 1997). Antosianin terutama terdapat pada kulit buah kersen. Penelitian ini menggunakan semua bagian buah kersen dalam pembuatan tepung buah kersen sebagai bahan substitusi biskuit.

\section{Kekerasan Biskuit}

Uji kekerasan biskuit dilakukan menggunakan uji penetrasi. Kekerasan menunjukkan ketahanan suatu bahan untuk pecah akibat pemberian gaya tekan. Selama proses pemanggangan biskuit, kepadatan adonan mengalami penurunan dan terbentuk struktur berongga. Pada saat yang sama tekstur yang penting dari biskuit terbentuk berupa kerenyahan disebabkan rendahnya kandungan gluten dan kelembaban.

Kekerasan biskuit kersen cenderung menurun dengan semakin meningkatnya substitusi buah kersen dan substitusi gula. Tepung buah kersen mengandung gum arab sebagai bahan pengisi atau enkapsulat. Hasil ini sejalan dengan penelitian Mudgil, Barak, \& Khatkar (2017) yang 


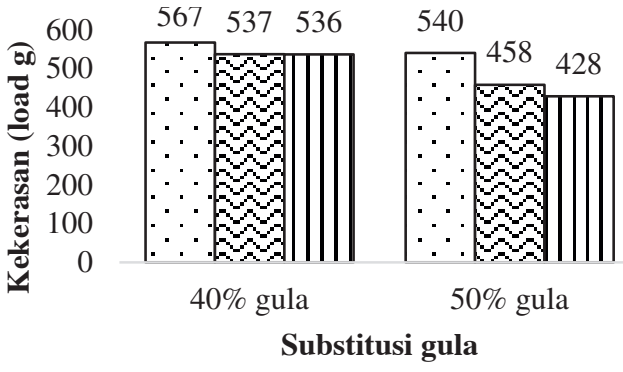

$\square 11 \%$ kersen $\square 17 \%$ kersen $\square 22 \%$ kersen

Gambar 1. Kekerasan Biskuit

menggunakan guar gum pada cookies. Guar gum menurunkan kekerasan cookies secara signifikan. Peningkatan substitusi gula dengan campuran gula sorbitol dan sukralosa juga turut berkontribusi pada penurunan kekerasan biskuit. Peningkatan sorbitol dalam biskuit bebas gluten menghasilkan tekstur yang kurang renyah (Aini, Affandi, \& Basito, 2016). Sorbitol bersifat mengikat air atau higroskopis. Penggunaan sorbitol pada produk panggang berbasis terigu menghasilkan penurunan kekerasan dibandingkan sukrosa (Srikaeo \& Thongta, 2015).

\section{KESIMPULAN DAN SARAN}

Pemanfaatan buah kersen dan substitusi gula dapat menghasilkan biskuit, mengandung gizi, antioksidan, dan lebih rendah kandungan gulanya. Buah kersen dapat meningkatkan aktivitas dan kadar antioksidan biskuit. Peningkatan subsitusi tepung buah kersen dan gula menurunkan kekerasan biskuit. Biskuit kersen memiliki peluang dikembangkan sebagai biskuit yang mengandung gizi dan antioksidan yang berguna untuk pencegahan faktor risiko penyakit tidak menular, overweight dan obesitas. Pengembangan lebih lanjut diperlukan pada penggunaan substitusi gula sorbitol yang lebih rendah atau kombinasi gula lainnya untuk meningkatkan karakteristik organoleptik dan fisik biskuit yang lebih disukai.

\section{ACKNOWLEDGEMENT}

Penelitian ini merupakan bagian dari tesis dengan judul Pemanfaatan Buah Kersen (Muntingia calabura L.) pada Biskuit sebagai Pangan Sumber Serat dan Antioksidan. Ucapan terima kasih peneliti sampaikan kepada Lembaga
Penelitian dan Pengabdian Masyarakat (LPPM) IPB University melalui hibah Penelitian Dasar Unggulan Perguruan Tinggi (PDUPT) yang telah mendanai sebagian penelitian ini. Ucapan terima kasih juga kepada komisi pembimbing yang telah memberikan saran dan masukan dalam pelaksanaan penelitian.

\section{DAFTAR PUSTAKA}

Aini, F. Y., Affandi, D. R., \& Basito. (2016). Kajian penggunaan pemanis sorbitol sebagai pengganti sukrosa terhadap karakteristik fisik dan kimia biskuit berbasis tepung jagung (Zea mays) dan tepung kacang merah (Phaseoulus vulgaris L.). Jurnal Teknologi Hasil Pertanian, IX(2).

Ajila, C. M., Leelavathi, K., \& Prasada Rao, U. J. S. (2008). Improvement of dietary fiber content and antioxidant properties in soft dough biscuits with the incorporation of mango peel powder. Journal of Cereal Science, 48(2), 319-326. doi: 10.1016/j.jcs.2007.10.001

Aksoylu, Z., \& Çag, Ö. (2015). Effects of blueberry, grape seed powder and poppy seed incorporation on physicochemical and sensory. Journal of Food Quality, 38, 164-174.

AOAC. (2005). Official Methods of Analysis of international. Gaithersburg, MD, USA: AOAC

Barbosa-Cánovas, G., Fernández-Molina, J., Alzamora, S., Tapia, M., López Malo, A., \& Chanes, J. (2003). Handling and preservation of fruits and vegetables by combined methods for rural areas: technical manual FAO agricultural services. Roma: Food and Agriculture Organization of the United Nations.

Bindels, L. B., Backer, F. De, Cani, P. D., Neyrinck, A. M., He, V. F. Van, \& Delzenne, N. M. (2013). Polyphenol-rich extract of pomegranate peel alleviates tissue inflammation and hypercholesterolaemia in high-fat dietinduced obese mice : potential implication of the gut microbiota. British Journal of Nutrition, (109), 802-809. doi: 10.1017/ S0007114512002206

Bittner, S. (2006). When quinones meet amino acids: chemical, physical and biological consequences. Amino Acids, 30, 205-224.

Cave, M., Hurt, R., \& Frazier, T. (2008). Obesity, inflammation, and the potential application of pharmaconutrition. Nutr Clin Prac, 23, $16-34$.

Farrell, N. J., Norris, G. H., Ryan, J., Porter, C. M., Jiang, C., \& Blesso, C. N. (2015). Black 
elderberry extract attenuates inflammation and metabolic dysfunction in diet-induced obese mice. British Journal of Nutrition, (114), 11231131. doi: 10.1017/S0007114515002962

Gentile, D., Fornai, M., Pellegrini, C., Colucci, R., Blandizzi, C., \& Antonioli, L. (2018). Dietary flavonoids as a potential intervention to improve redox balance in obesity and related co-morbidities : a review. Nutrition Research Reviews, 1-9. doi: 10.1017/ S0954422418000082

Gomathi, R., Anusuya, N., \& Manian, S. (2013). A dietary antioxidant supplementation of Jamaican cherries (Muntingia calabura L.) attenuates inflammatory related disorders. Food Science and Biotechnology, 22(3), 787-794. https://doi. org/10.1007/s10068-013-0146-1

Kemenkes. (2018). Laporan Nasional Riskesdas 2018. Retrieved from www.litbang.kemkes. go.id

Kumar, S., Sandhir, R., \& Ojha, S. (2014). Evaluation of antioxidant activity and total phenol in different varieties of Lantana camara leaves. BMC Research Notes, 7, 560. doi: 10.1186/1756-0500-7-560

Lao, F., \& Giusti, M. M. (2015). Quantification of purple corn (Zea mays L.) anthocyanins using spectrophotometric and HPLC approaches: method comparison and correlation. Food Anal. Methods. doi: 10.1007/s12161-015-0318-0

Manzocco, L., Calligaris, S., Mastrocola, D., Nicoli, M., \& Lerici, C. (2001). Review of nonenzymatic browning and antioxidant capacity in processed foods. Trends Food Sci. Tech, 11, 340-346.

Miean, K. H., \& Mohamed, S. (2001). Flavonoid (myricetin, quercetin, kaempferol, luteolin, and apigenin) content of edible tropical plants. $J$. Agric. Food Chem, 49, 3106-3112.

Molyneux, P. (2004). The use of the stable free radical diphenylpicryl-hydrazyl (DPPH) for estimating antioxidant activity. Songklanakarin J. Sci. Technol, 26(2), 211-219.

Mudgil, D., Barak, S., \& Khatkar, B. S. (2017). Acceptability of cookies as a function of soluble dietary fiber, baking time and different water levels. LWT - Food Science and Technology, 80, 537-539.

Muslimin, L., Hasyim, I., Yusuf, N. F., Mubarak, F., \& Yulianty, R. (2019). Nutrient content, mineral content and antioxidant activity of Muntingia calabura Linn. Pakistan Journal of Nutrition, 18, 726-732. doi: 10.3923/pjn.2019.726.732
Nielsen, S. S. (Ed.). (2010). Food Analysis (4th ed.). New York, USA: Springer. doi: 10.1007/9781-4419-1478-1

Ou, J., \& Wang, M. (2019). Positive and negative effects of polyphenol incorporation in baked foods. Food Chemistry, 284, 90-99. doi: 10.1016/j.foodchem.2019.01.096

Pasqualone, A., Bianco, A. M., Paradiso, V. M., Summo, C., Gambacorta, G., \& Caponio, F. (2014). Physico-chemical, sensory and volatile profiles of biscuits enriched with grape marc extract. FRIN, 65, 385-393. doi: 10.1016/j. foodres.2014.07.014

Pasqualone, A., Maria, A., Michele, V., Summo, C., Gambacorta, G., Caponio, F., \& Blanco, A. (2015). Production and characterization of functional biscuits obtained from purple wheat. Food Chemistry, 180, 64-70. doi: 10.1016/j. foodchem.2015.02.025

Pereira, G. A., Arruda, H. S., de Morais, D. R., Eberlin, M. N., \& Pastore, G. M. (2018). Carbohydrates, volatile and phenolic compounds composition, and antioxidant activity of calabura (Muntingia calabura L.) fruit. Food Research International, 108, 264-273. doi: 10.1016/j. foodres.2018.03.046

Pereira, G. A., Tomé, P. H. F., Arruda, H. S., Fragiorge, E. J., \& Ribeiro, P. R. (2016). Physicochemical characterization and antioxidant activity of Calabura fruit (Muntingia calabura L.). Brazilian Journal of Food Research, 7(2), 67. doi: 10.3895/rebrapa.v7n2.3526

Preethi, K., Vijayalakshmi, N., Shamna, R., \& Sasikumar, J. M. (2010). In vitro antioxidant activity of extracts from fruits of Muntingia calabura linn. from India. Pharmacognosy Journal, 2(14), 11-18. doi: 10.1016/S09753575(10)80065-3

Recuenco, M., Lacsamana, M. S., \& Sabularse, V. (2016). Total phenolic and total flavonoid contents of selected fruits in the Philippines. Philippine Journal of Science, 145 (3)(January), 275-281.

Saputri, I., \& Damayanthi, E. (2015). Penambahan pegagan (Centella asiatica) dengan berbagai konsentrasi dan pengaruhnya terhadap sifat fisiko-kimia cookies sagu. Jurnal Gizi Dan Pangan, 10(2), 149-156. https://doi. org/10.25182/jgp.2015.10.2.\%p

Siervo, M., Montagnese, C., Mathers, J. C., Soroka, K. R., Stephan, B. C. M., \& Wells, J. C. K. (2013). Sugar consumption and global prevalence of obesity and hypertension : an ecological 
analysis. Public Health Nutrition, 17(3), 587596. doi: 10.1017/S1368980013000141

Srikaeo, K., \& Thongta, R. (2015). Effects of sugarcane, palm sugar, coconut sugar and sorbitol on starch digestibility and physicochemical properties of wheat based foods. International Food Research Journal, 22, 923-929.

Srivastava, P., Indrani, D., \& Singh, R. P. (2014). Effect of dried pomegranate (Punica granatum) peel powder (DPPP) on textural, organoleptic and nutritional characteristics of biscuits. Food Science and Nutrition, 65(7), 827-833. doi: 10.3109/09637486.2014.937797

Stapleton, A. P., James, E. M., Goodwill, G. A., \& Frisbee, J. C. (2008). Obesity and vascular dysfunction. Pathophysiology, 15, 79-89.

Sun, J., Chu, Y., Wu, X., Hai, R., \& Liu. (2002). Antioxidant and antiproliferative activities of common fruits. Journal of Agricultural and Food Chemistry, 50, 7449-7454.
Susantiningsih, T. (2015). Obesitas dan Stres Oksidatif. Jurnal Kesehatan Unila, 5.

Syafiq, A., Setiarini, A., Utari, D.M., Achadi, e.1., Fatmah, Kusharisupeni, ...Indrawani, Y.M. (2014). Gizi dan Kesehatan Masyarakat. Jakarta: Rajawali Pers.

Tańska, M., Roszkowska, B., \& Czaplicki, S. (2016). Effect of fruit pomace addition on shortbread cookies to improve their physical and nutritional values. Plant Foods Hum Nutr, 71, 307-313. doi: 10.1007/s11130-016-0561-6

Vongsak, B., Sithisarn, P., \& Mangmool, S. (2013). Maximizing total phenolics, total flavonoids contents and antioxidant activity of Moringa oleifera leaf extract by the appropriate extraction method. Industrial Crops \& Products, 44(November 2017), 566-571. doi: 10.1016/j. indcrop.2012.09.021

Wang, H., Cao, G. H., \& Prior, R. L. (1997). Oxygen radical absorbing capacity of anthocyanins. $J$. Agric. Food Chem, 45, 304-309. 